\section{Which way now for Europe?}

SIR-Your leading article (Nature 346, $203 ; 1990$ ) deriding the indiscretions of $\mathrm{Mr}$ Nicholas Ridley quite missed the point of what he was saying. He was not saying, as you impute, that "rigid genetic determination" assures German domination. The view that he was expressing, and which is shared by many other people (perhaps not such a minority as the disclaimers of his ideas have hastened to imply), is that in the German position lies the seat of forces which, in my lifetime, have generated three major struggles to dominate Europe. The third is clearly in progress.

Those forces are associated with its geography, compactness, social attitudes and practices, natural resource limitations, possibly a different genetic mix from that of its neighbours - I know of no "respectable biologist" who would claim it to be identical - and many other factors, some traditional, some imposed afresh on each new generation by its uniquely landlocked situation. They have not only pushed the German people into two world wars this century, but have also inspired them to behave in ways so far beyond the pale of civilized human conduct that they have outraged the whole world - a triviality that you ignore. The partition of Germany in 1945 and the emergence of two

\section{To go or not to go}

SIR - When invited to visit colleagues in Beijing, I too asked myself (Nature 346, $594 ; 1990)$ whether my visiting China would be perceived as implicit support for its present government. After ascertaining that the American Physical Society had no clear policy on individual visits to China (as opposed to attendance at officially organized conferences), I asked several of my colleagues from the People's Republic of China. Remarkably, the response to my question "Should I go?" was unanimous: all felt that individual visits, so long as they were not government-sponsored, could only benefit scientists working in China, and I was actually encouraged to make my trip. The same response was given by this university's Chinese Student and Scholar Association, which is not known for pro-Li sentiment, and which presumably is immune to any bias that might inhibit a colleague from discouraging the travel plans of another.

Ironically, after obtaining this "clearance' and my visa, I was unable to make the trip. However, in the absence of new data or arguments, I would not hesitate to visit colleagues there in the future.

Physics Department,

Michael H. Salamon

University of Utah,

Salt Lake City, Utah 84112, USA superpowers, with the (perhaps only) common objective of suppressing a recurrence of a German-led domination, has proved to be only partly efficacious in achieving this objective.

What many fear is that these forces, which have inspired the Germans to such superior economic performance, even within these postwar constraints, will, now that partition is ended, Germany unified and the superpowers down to a single, far-distant one, move the German nation to use other forms of domination in the course of time if political and economic domination prove inadequate for the German appetite. I know of no reason why a unified Germany of AD 2000 should have feelings, ideas, aspirations, hopes, resentments and fears different from a unified Germany of AD 1900 or 1930 - or why it should act differently. That the Germans have so far been contained to the expression of economic domination is no guarantee that, now free from this containment, they will be content to act as though the constraints of partition and the Warsaw pact were still in place and NATO obligations binding.

\section{Acomb High House,}

Acomb, Hexham,

Northumberland NE46 4PH, UK

SIR-By referring to Mr Nicholas Ridley's recent Spectator interview in which he revealed his concern about German characteristics, as an "outburst", you accuse him of being intemperate.

But this is not the main substance of your complaint. You have inferred that his concern about German characteristics indicates his belief in their genetic determination. You go on to express outrage that such a view could be held by grownup people against the beliefs of respectable biologists.

First, this response is as intemperate in tone as were Ridley's original utterances, betraying a depth of feeling inappropriate to the dispassionate and disinterested posture of a scientific journal of Nature's standing. Second, there is no reason to believe that Ridley believes that German characteristics are necessarily genetic in origin. Indeed, later in your article, you allow that such characteristics as can be determined (in so far as Ridley apparently fears them) are "recognizably the products of social institutions".

Whether the product of social institutions or inherited, Ridley may argue, these characteristics are equally to be feared.

It seems that you have used the Ridley "outburst" as an opportunity to express a dogmatic position in the 'nature versus nurture' argument - which argument is clearly not relevant to Ridley's fears. Thus, far from demonstrating the "primitive roots" of Ridley's views, you have used the primitive methods of guilt-byassociation in aligning Ridley's views with those who believe in the influence of genetics on behaviour.

C. G. Jung's views concerning the behaviour of Germans and other groups remain deeply unpopular in some quarters as they appeared to fuel the Nazi obsession with race - in Jung's case also there is no reason to believe that he considered inheritance to be the mode of passing national characteristics from generation to generation.

No, the legitimate fear of identifying national or racial characteristics is that this can lead to discrimination against vulnerable minority groups. This fear should not be confused with the fear of the uprising of a traditionally assertive nation.

If there remains doubt concerning the pedigree of the perception by nonGermans of German characteristics, further reference should be made to Tacitus, whose description of German characteristics in Germania is very similar to the observations of some more modern commentators of Ridley's persuasion.

J. F. MACKENZIE

Royal Infirmary, Glasgow G4 OSF, UK

\section{Ice-out in Maine}

SIR - The folks up in northern Maine have kept an accurate record of the time of ice-out on their largest lake, Moosehead Lake, for the past 142 years. In the spring, ice-out comes suddenly, usually in one day. Moosehead Lake was the centre of the logging industry in the late nineteenth and early twentieth century, and ice-out in the spring meant fresh supplies by steamboat to the isolated logging camps on the Northeast Carry. So ice-out, like Christmas, was celebrated, remembered and luckily recorded. More recently, ice-out contests have been sponsored by the Moosehead Lake Region Chamber of Commerce. Thus, an exact record of the date of this event each year since 1848 has been preserved. When the dates are plotted and the best fit line drawn, it appears that on average ice-out occurs

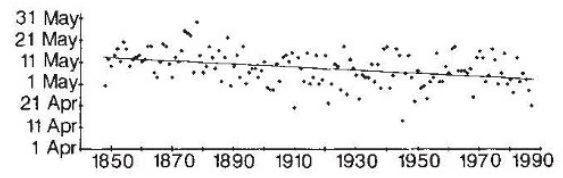

about 10 days earlier now than in 1848 . Perhaps these data will be of interest to those studying climate change, but up here in Maine we are going to take them seriously and start reducing greenhouse gases.

Frost Pond,

DONALD G. COMB

Maine, USA

NATURE · VOL $347 \cdot 11$ OCTOBER 1990 